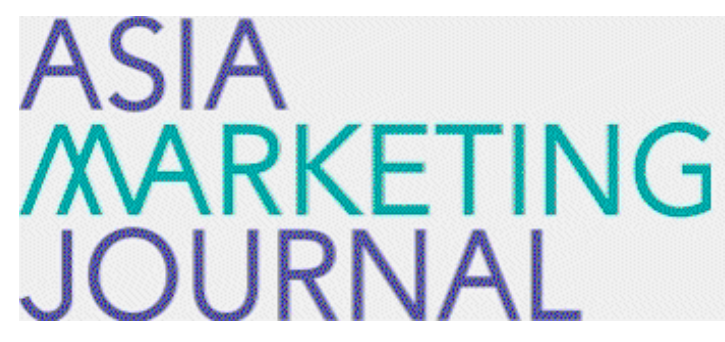

ASIA MARKETING JOURNAL

Volume 18 | Issue 2

Article 4

7-31-2016

\title{
A Comparative Study on Antecedents to the Customer Satisfaction with Cross-Border E-commerce in Korea and China
}

Bai Ting

Inwoo Nam

Follow this and additional works at: https://amj.kma.re.kr/journal

Part of the Marketing Commons

\section{Recommended Citation}

Ting, Bai and Nam, Inwoo (2016) "A Comparative Study on Antecedents to the Customer Satisfaction with Cross-Border E-commerce in Korea and China," Asia Marketing Journal: Vol. 18 : Iss. 2 , Article 4. Available at: https://doi.org/10.15830/amj.2016.18.2.63

This Article is brought to you for free and open access by Asia Marketing Journal. It has been accepted for inclusion in Asia Marketing Journal by an authorized editor of Asia Marketing Journal. 


\title{
A Comparative Study on Antecedents to the Customer Satisfaction with Cross-Border E-commerce in Korea and China
}

\author{
Bai Ting* \\ Inwoo Nam**
}

\begin{abstract}
As one of the most popular forms of electronic commerce, cross-border e-commerce provides numerous consumer benefits, such as broad and deep product assortments at low prices. However, consumers tend to exhibit high involvement in cross-border e-commerce purchases due to high risks associated with such purchases.
\end{abstract}

The paper focuses on identifying causal relationships between e-commerce website traits (i.e., website trustworthiness, interactivity and convenience) and consumer satisfaction and along with loyalty. We proposed a reflective - reflective hierarchical model (first-order reflective and second-order reflective model) and used the Partial Least Square Analysis Statistical method to test the hypotheses.

The results demonstrated that website trustworthiness, convenience and interactivity were all positively related to consumer satisfaction. Also, higher satisfaction led to stronger customer loyalty, which may well increase revisit intentions. We also compared the strength of each path from a website trait to satisfaction. Results illustrated that the path from website convenience to satisfaction is the strongest among the three website traits.

In addition, we separately examined differences within Korean group and Chinese group. No statistically significant difference among website traits was found within Korean group. However, within Chinese group, we found that website convenience is the most important predictor of satisfaction. This indicates that Chinese consumers are more concerned about the website convenience than interactivity and trustworthiness when they make cross-border e-commerce purchases.

Moreover, this study investigated possible differences between Korean and Chinese group. We used multi-group analysis of Smart PLS 3.0 to test the results. It was shown that the two groups do not display statistically significant difference in trustworthiness, interactivity, or convenience in influencing customer satisfaction.

Finally, we presented further implications which are useful for understanding of the proposed model. Limitations and improvements of this research were presented, too.

Key words: cross-border e-commerce, trustworthiness, interactivity, convenience, consumer loyalty

\footnotetext{
* Haco Co. Ltd. (Baiting123@naver.com), First Author

** College of Business and Economics Chung-Ang University (inam@cau.ac.kr), Corresponding Author
} 


\section{Introduction}

Cross-border e-commerce refers to international online trade which entails a buyer purchasing products from a seller across national borders. In 2012, cross-border e Commerce sales reached $\$ 300$ billion, while global online trade is expected to soar to $\$ 1.4$ trillion by 2015 , presenting multi-channel retailers with limitless business opportunities for international $\mathrm{ex}^{-}$ pansion (McDermott, 2015). Consumers believe that the major advantage of the cross boarder e-commerce is that it provides broader and deeper product assortments compared to domestic market and also offers better quality products. Cross-border e-commerce is also costefficient for consumers since purchasing directly from the sellers via online shop is generally cheaper than buying from domestic importers.

In spite of growing popularity that crossborder e-commerce is experiencing, customers are also concerned with this new mode of shopping. According to a survey (Back, 2013), many participants were dissatisfied with $\mathrm{ex}^{-}$ change and refund processes, unstandardized product quality and insufficient after-services. They believed that those are major areas of cross-border shopping environment to be improved. Therefore, the key challenge lying ahead of cross-border e-commerce is to understand customers' needs in order to enhance customer satisfaction.

64 ASIA MARKETING JOURNAL Vol. 18 No. 02 July 2016
There are some traits of $\mathrm{e}^{-\mathrm{comm} e r c e}$ that exercise large influence over consumer's decision making process in choosing a specific e-commerce websites. For example, previous studies showed that perceived trustworthiness of a website is one of the most important factors that influence consumers' preference on domestic e-commerce websites (Balasubramanian, Konan and Menon, 2003, Spekman, 1988). This research will examine how some traits of a website affect consumers' intention to revisit a cross-border website. Compared with the domestic e-commerce, cross-border e-commerce is more susceptible to potential complications such as language differences, fluctuating exchange rate, inconsistent delivery lead time and network system risks, thus having a higher risk of making a transaction. This is particularly true when it comes to resolving complaints caused by delivery failure, product defect or wrongful billing In fact, given that the prices of the products are same, most people would prefer to purchase from domestic online store rather than from foreign online stores.

In this study, we propose that websites' trustworthiness, interactivity and convenience will have positive impact on consumers' satisfaction and eventually lead to the customer loyalty to websites.

We will also attempt to make a comparative study between Chinese consumers and Korean consumers based on the important traits of cross border e-commerce. Historical, geographical and 
cultural relationship between the two countries is largely influencing consumption behaviors in both countries. For instance, "Korean Wave" attracts many of young Chinese consumers to purchase cosmetics and accessories made in Korea. Correspondingly, Korean consumers are attracted to low-price Chinese commodities such as agricultural products and handmade goods (Tang, 2014).

Along with the Korea-China Free Trade Agreement (FTA), firms in both countries have better chances in making further advances into the each other's domestic market with reduced tariff (Choi, 2012). Similarly, it can also be predicted that the cross-border e-commerce trade between the two countries will flourish. However, the most important factor to consider in cross border $\mathrm{e}^{-}$commerce between China and Korea is not tariff. To be more specific, one survey about cross-border e-commerce conducted by KCCI (the Korea Chamber of Commerce \& Industry) in 2013, showed that the most important reasons for Koreans consumers to buy product though cross-border e-commerce are price incentives and access to the products not available in Korea (Back, 2013). However, Chinese consumers said that product quality and shopping convenience are the main reasons they make cross-border purchase (Han and Chen, 2012). In this research we will compare the three antecedents (trustworthiness, convenience, interactivity) to the e-satisfaction in the cross-border e-commerce within and be- tween the countries. We will also illustrate that the relative importance of those three antecedents might not be quite different across the country, but their importance within each county might be different.

\section{Theoretical Background}

\subsection{Cross-border e-commerce}

Cross border- $\mathrm{e}^{-}$commerce is a type of electronic commerce. E-commerce refers to the use of the Internet and the Web to transact business (Damanpour, 2001). E-commerce can be divided into domestic e-commerce where customer purchase a product from a retailer in the same county and cross-border e-commerce where customer purchase a product from a retailer in a different county (Kim and Park, 2013, see Figure 1).

Cross - border electronic commerce shopping is expected to continue growing rapidly for it has a lot of incentives including: 1) convenience such as time and energy saving, 2) a wide range of selections, 3) more inexpensive than offline shopping, 4) easily access to the comparative information than other products, 5) easy to find rare products (Lee 2013; Civic Consulting, 2012). However, competing with traditional domestic offline shopping, cross-border electronic commerce is not always successful 
〈Figure1〉 Source: "Is Cross - Border E-commerce Silk Road or mirage?" written by Kim and Park, in 2013

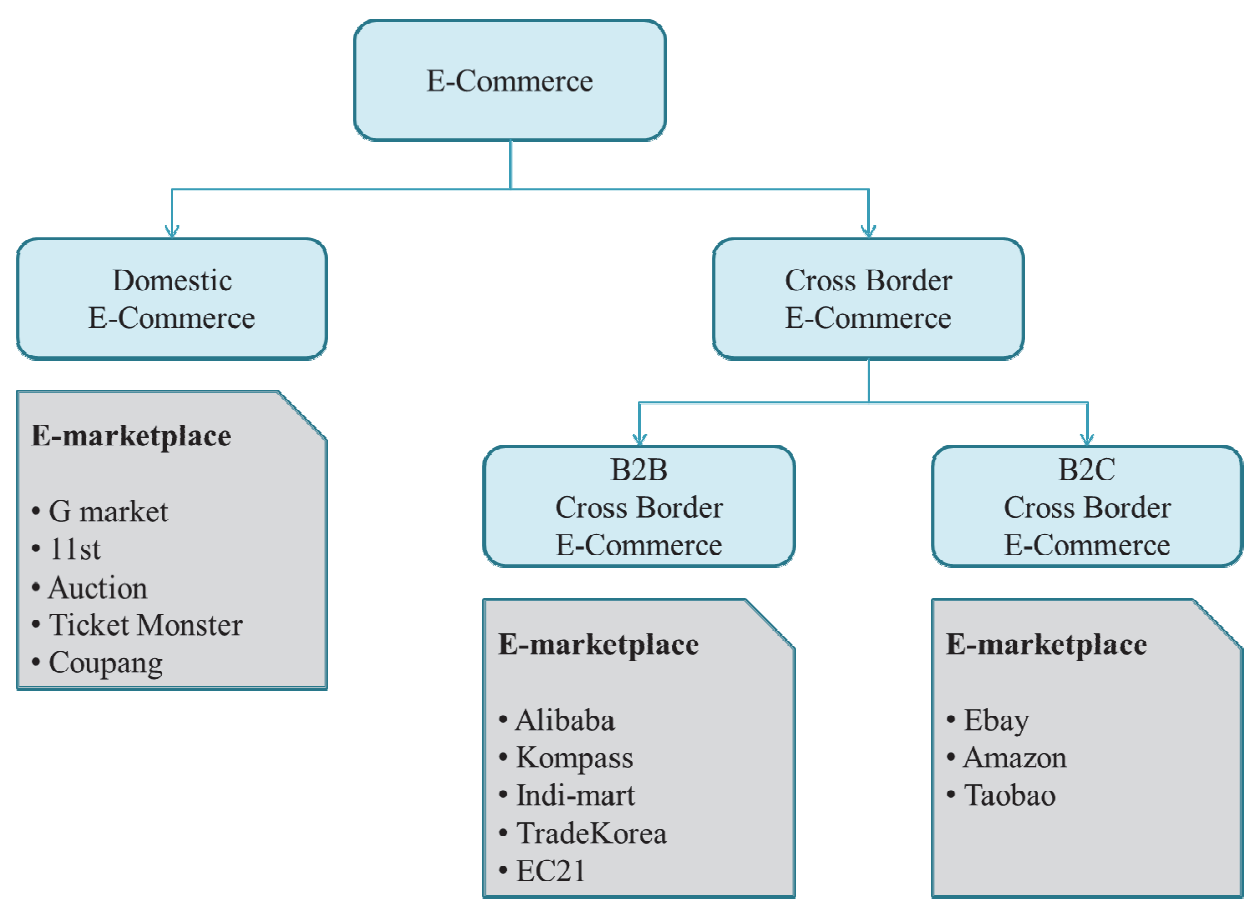

because of its uncertainty and disadvantages which includes longer delivery time, uncertain products' quality, complex process to return and exchange, warranty issues, privacy issues when using Internet e-payment system. Also, one survey conducted by Flash Eurobarometer within the EU countries (European Commission, 2013) reports that a majority of people feel more confident in domestic e-commerce than in the cross-border e-commerce. The results showed that consumers were wary of shopping through the websites built in another country.

\subsection{Important traits of cross-border e-commerce}

Cross-border e-commerce is a type of $\mathrm{e}^{-}$ commerce. E-commerce literature has identified important antecedents for customer satisfaction or loyalty. According to our review, the most frequently discussed antecedents are trustworthiness of the website, website interactivity and convenience of website for example, Reichheld and Schefter (2000) argues that the most important factor consumers use to assess e-commerce websites is the level of trustworthiness. Coker (2013) also found that the most important factor affecting consumers' satisfaction in the 


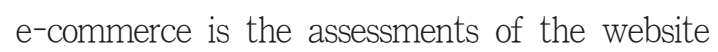
trustworthiness.

Interactivity is also an important factor to manage the relationship between $\mathrm{e}^{-}$commerce websites and customers. One of the barriers to the growth of $\mathrm{e}^{-}$commerce is that customer do not have face-to-face or voice-to-voice interactions with salespeople or store managers. Due to this fact, customers experience uncertainty or discomfort associated with making a purchase online (Choi and Rifon, 2002). Extant research on interactivity suggests the important role of interactivity of the website in enhancing relationship building with customers in the online environment (Feinberg and Kadam, 2002; Fiore, Jin, and Kim, 2005; Heldal, Sjovold, and Heldal, 2004; Jo and Kim, 2003; Thorbjornsen et al., 2002). These findings suggest interactivity between website and customers should be included as a crucial antecedent that influences relationship between an e-commerce company and its customers in the online shopping environment.

Literature in the e-commerce also identified the convenience as a very influential factor to the customer satisfaction in the e-commerce environment. Studies on consumers' motivations to purchase products online suggest that convenience is a primary factor affecting customers' purchase decisions (Tracy, 1998). This finding is echoed by another research, which demonstrated that online customers are convenience oriented (see Constantinides, 2004; Donthu and Garcia, 1999; Korganonkar and Wolin, 1999).
In fact, convenience is one of the most important advantages for online shopping (Bhatnagar et al., 2000).

As a type of e-commerce these three factors are also important antecedents to the customer satisfaction in cross-border e-commerce. In fact, we believe that they are even more important in the cross-border e-commerce than domestic $\mathrm{e}^{-}$-commerce. Trustworthiness is more important in the cross-border e-commerce because the cross-border e-commerce has higher risk and uncertainty due to the questionable product authenticity and delivery failure. It cannot easily interact with customer as does the domestic e-commerce since languages, time, and culture may differ country to country. Finally, crossborder e-commerce is less convenient because it may have different payment options and return policy from those used in buyer's country. These conditions of the cross-border websites make trustworthiness, interactivity, and convenience even more important in the cross $^{-}$ border e-commerce setting. Thus, in our study, we propose that website trustworthiness, interactivity and convenience are the three important antecedent of customer satisfaction.

In the next section we will review the literature regarding the constructs used in this research

\subsection{Trust and website trustworthiness}

Trust is a willingness to rely on an exchange 
partner's reliability and integrity in whom one has confidence (Moorman et al., 1993). Trust is important for successful transactions (Smith and Barclay, 1997).

There are many aspects of customers' trust on the websites. According to the previous research on trust in the $\mathrm{e}^{-}$commerce, those factors can be categorized into four dimensions; security assurance (Park and Kang, 2000), size \& reputation (Jarvenpaa, Tractinsky and Vitale 2000), product quality and delivery service (Ann, Ryu and Han, 2004).

\subsubsection{Security assurance}

Security assurance of a website can be defined as the guarantees whether or not a website is able to protect consumer's confidential information collected during electronic transactions from unauthorized use or disclosure (Belanger, Hiller and Smith, 2002).

In 2001, Harris conducted a survey named "Harris Interactive for the Privacy Leadership Initiative" which studied how consumers are concerned with online privacy issues. The survey revealed that the reason for some respondents are reluctant to make a purchase on the internet is lack of security of information (Walter, 2001).

Hoffman and his colleagues (1999) suggested that online consumers' perception of security assurance and privacy protection will influence their perceived trust of the websites. Security and privacy assurance are essential for supporting the growth of the trustworthiness B2C e-commerce (Belanger, Hiller and Smith, 2002).

\subsubsection{Delivery service}

Delivery is one of the most effective ways to build up customers' trust on the e-commerce site (Urban, Sultan, and Qualls 1999). A reliable and timely delivery will enhance online consumers' trust toward internet shopping (Park and Kang, 2000). If delivery failure occurs (e.g., delayed delivery, delivery of wrong or damaged product), consumer may lose his/her trust in the website. Since online shopping has more uncertainty than shopping in offline stores, customer might need more generous return policy even if no serious mistake was made at seller's side. Websites that allow customers to return the ordered products within a specified period of time are perceived as more trustworthy to the customers (Keeney, 1999).

\subsubsection{Product quality}

Previous research suggested that product quality is one of the fundamental objectives to enhance consumers' perception of websites' trustworthiness (Keeney, 1999). Consumers are likely to visit a cross-border website offering various and high-quality products. If the products quality meets consumers' expectation, consumers tend to trust the site. 


\subsubsection{Size \& reputation}

In the traditional offline shopping malls, buyers often use store size to evaluate whether or not the seller is trustworthy (Doney and Cannon, 1997). Customers often considers a bigger firm to be more trustworthy because size of a firm is a clear evidence that the firm has been successful in the market and therefore it is more likely to meet promises it made to its customers (Donny and Canon, 1997). Customers also believe that the bigger firms have better expertise and more resources for establishing supporting system such as customer and technical services (Chow and Holden 1997). Likewise, having a big store visualizes firm's capability to offer such services. (Jarvenpaa, Tractinsky and Vitale 2000).

Reputation refers to the extent to which a buyer believes a seller is honest and concerned about its consumers (Doney and Cannon, 1997). It is reasonable for consumers to believe that a firm with a good reputation is trustworthy because such firm would not take risk to jeopardize its reputational assets by displaying opportunistic behavior (Chiles and McMackin 1996). This can be applied to the field of $\mathrm{e}^{-}$commerce as well. A website with good reputation can make their customers trust the website because it assures customers that they will receive their orders on time and the quality of products is guaranteed (Jarvenpaa, Tractinsky and Vitale 2000).

\subsection{Interactivity}

Interactivity can facilitate persons and organizations to communicate with others (Blattberg and Deighton, 1991). McMillan and Hwang, (2000) presented that users rated interactivity of sites on the basis of their perceptions of two-way communication, level of control, user activity, sense of place, and time sensitivity. Following McMillan and Hwang (2000), Liu (2003) developed the scales to measure interactivities in the websites under three distinct dimensions; active control, two-way communication, and synchronicity. He showed that an interactive communication can offer individuals active control and allows them to communicate reciprocally and synchronously. In this regard, the study proposed that the interactivity of cross-border website has three dimensions as Liu (2003) suggested. We will discuss those three dimensions in the following section.

\subsubsection{Active control}

Control is the core component of construct in the definitions of interactivity (Bezjian Avery, Calder, and Iacobucci, 1998). Active control refers to voluntary and instrumental action which directly influences users' experience directly (Liu, 2003). Active control can describe a user's ability to voluntarily participate in and instrumentally influence a communication (McMillan and Hwang, 2000). Participants in an interactive communi- 
cation should be able to exert control on the information exchanged, which includes both sent and received information (Jensen, 1998)

\subsubsection{Two-way communication}

Another dimension of interaction is two- way communication. Pavilk (1998) suggested that interactivity means two-way communication between source and receiver, or, more broadly, multidirectional communication between any number of sources and receivers. In e-commerce, two-way communication is characterized by the ability for reciprocal communication between website retailers and users or users and users (Liu and Shrum, 2002). With the two-way communication, consumers can provide feedbacks to e-commerce retailers.

\subsubsection{Synchronicity}

Synchronicity is defined as the degree to which users' input into a communication and the responses they receive from the communication are simultaneous (McMillan and Hwang, 2000). The speed of the interaction between the web site and the customer is also important to the interactivities. It can be decided by factors such as waiting time, loading time of the web contents, and degree to which interacting with the web is slow and tedious (Hoffman, Novak and Peralta, 1999).

\subsection{Convenience}

In the marketing literature, the concept of convenience was introduced by Copeland (1923) as a form of product classification; convenient goods which are purchased frequently and immediately at easily accessible stores. Later on, in the traditional retailing context, two factors are known as important drivers for the convenience; time saving and effort minimization. (Etgar, 1978; Kotler and Zaltman, 1971; Seiders et al., 2000, 2005, 2007; Yale and Venkatesh, 1986). In the service industry, Berry et al. (2002) argued that the convenience construct is a multidimensional construct comprising the dynamic processes of sub dimensions of convenience. Those sub dimensions of convenience in service are integrated in five dimensions of Servcon by Seiders et al. (2007) ; 1) decision (easy to determine what to shop), 2) access (easy to $\mathrm{ac}^{-}$ cess the service), 3) search (easy to identify and select products they wish to buy), 4) transaction (easy to complete the transaction), and 5) post-benefit convenience (easy to take care of returns and exchange). In the following $\mathrm{sec}^{-}$ tion we will discuss access, search and transaction convenience. We decided not to cover decision convenience. For offline shoppers, "decision convenience" is the primary concern because it refers to the convenience of making a quick decision on where to visit and find desired products. However, for e-commerce both can be done in matter of seconds, on customer's 
desk. Therefore the decision convenience is almost inapplicable (Beauchamp and Ponder, 2010). Post-benefit convenience is also not included in the convenience construct. It is often related to a consumer's need for product exchange which occurs when product or service fails to meet its expected performance (Berry et al., 2002). In this research those issues are covered by the trust construct.

\subsubsection{Access convenience}

Access convenience occurs prior to the actual service exchange (Berry et al., 2002). It refers to the degree of perception of time and effort costs to access the service. Previous studies determined access convenience by the operating hours, physical location, and availability online, by phone, or in person (Meuter et al., 2000). The lower time cost is required for consumers to receive the service, the higher degree of $\mathrm{ac}^{-}$ cess convenience will be perceived (Seiders, Berry and Gresham, 2000). Under traditional offline service, access convenience relates to parking, location and opening hours, while online access convenience relates to website accessibility and unlimited access to shopping (Jiang, Yang and Jun, 2012).

\subsubsection{Search convenience}

Seider et al.(2000) suggest that the search convenience is associated with the time and effort needed when consumers are trying to identify and select products they wish to buy. For online customers, they can search products and compare costs without physically visiting multiple stores to find their desired products. Thus, search convenience in $\mathrm{e}^{-}$commerce is affected by download speed, web site design, search function in the site and product classification (Jiang, Yang and Jun, 2012). Since online shoppers are often faced with an extensive product assortment and a limited amount of time to make a decision, e-commerce carefully design their websites for the customers to easily navigate the site and search the products (Beauchamp and Ponder, 2010). Also some online retailers offer decision aids (i.e., recommendation agents and shopping bots) to make the information search process and the formation of a consideration set more convenient for consumers (Punj and Moore, 2009).

\subsubsection{Transaction convenience}

Transaction convenience becomes salient once the service exchange process has been initiated (Seider et al., 2007). It is defined as the speed and ease with which consumer can effect and amend transactions" (Seider et al., 2000). The less time and effort spent in physical or remote queues, more transaction convenience will be perceived by consumers (Kumar, Kalwani and Dada, 1997).

In the online shopping setting, consumer per- 
ceived online shopping convenience can dramatically be improved when the online retailers provide simple and flexible payment methods (Morganosky and Cude, 2000).

\subsection{Satisfaction and loyalty}

Satisfaction can reflect a positive outcome from the fulfillment of consumers' needs (Bearden and Teel, 1983). Consumer satisfaction in the online shopping can be the extent to which the perceptions of consumers' online shopping experience confirm their expectations ( $\mathrm{Li}$ and Zhang, 2002). Loyalty is a biased behavioral purchase process that results from a psychological process (Jacoby, 1971). Those who like a brand or have a favorable attitude towards a brand or a store will purchase the brand or shop in those stores consistently over time (Assael, 1992; Keller, 1993). Consumers' attitude towards websites' convenience and security concerns positively influence their post purchase satisfaction which leads to the customer loyalty toward the websites (Reibstein 2002). In this research, we will focus on analyzing the determinants of consumer satisfaction towards the cross-border e-commerce, including websites' trustworthiness, interactivity and convenience.

In the next section, we will discuss hypothesis based on the construct explained above.

\section{Hypothesis Development}

Trust establishes a long-term buyer-seller relationship (Spekamn, 1988) and is a critical underpinning of a positive shopping experience in the electronic commerce (Jarvenpaa, Tractinsky and Vitale, 2000). As discussed in the previous section, four aspects of cross-border e-commerce websites traits were adopted as sub dimensions of trustworthiness in this research; security assurance (Park and Kang, 2000), size \& reputation (Jarvenpaa, Tractinsky and Vitale 2000), product quality and delivery service (Ann, Ryu and Han, 2004).

In the Cross-border e-commerce, crucial information (e.g. product information, return policy etc.) could be presented in foreign languages, which increase consumer's anxiety in making a purchase. Also, when faced with privacy issues, it may be more difficult for consumers to handle those problems due to the distances between countries or language obstacles. Therefore, lack of security becomes a greater threat in cross-border $\mathrm{e}^{-}$-commerce than it is in domestic e-commerce.

In the context of cross-border e-commerce, geographical distances and time differences between countries are major hindrances in achieving fast and accurate delivery. Likewise, delivery failure is more likely to happen. Thus, customers of cross-border e-commerce appreciate a timely, accurate and reliable delivery 
services. Conversely, if deliveries are always late or inaccurate, the consumers will lose trust in the website and switch to alternative websites (Ahn, Ryu and Han, 2007).

Consumers are more likely to visit a crossborder website to purchase higher-quality merchandises at a cheaper price than in the domestic market (Han and Chen, 2012). Thus, product quality is one of the most important factors influencing perceived trustworthiness (Keeney, 1999). If an online store offers poor quality products, the image of the store will be damaged. This is especially true in the crossborder e-commerce where "knockoff (fake) product" cannot be completely filtered.

A big e-commerce websites can signal to potential customers that the website is able to reduce the risk of product failure. Good reputation signals past forbearance of opportunism (Smith and Barclay, 12997). Customer's perceived that a site with good reputation would not act opportunistically, which may jeopardize its own reputation.

Traditionally, a large numbers of research showed a strong positive relationship between trust and customer satisfaction. For example, Morgan and Hunt (1994) recognized the important role of trust in shaping customer's satisfaction. Singh and Sirdeshmukh (2000) proved that the trust will have a direct impact on customer's post-purchase satisfaction. Even in the e-commerce settings, trust is empirically found to be a strong predictor of satisfaction
(Chang and Chen, 2009; Chiu et. al 2009). Trust is especially important in transactions which contain elements of risk and vulnerability (Reichheld and Schefter, 2000). In the line with this argument we can say that the trust might be even more important in the cross-border e-commerce market where more risk and uncertainty is involved than the domestic e-commerce market. Therefore we propose that:

\section{H1: Trustworthiness of the cross-border $e^{-}$ commerce website is positively related to consumers' satisfaction.}

Consumers define online service as a degree of the interaction between the consumer and the shopping websites (Bitner et al., 1990). It is necessary for websites to understand interactivities with their customers so that they can engage and interact with them effectively (McMillan and Hwuang, 2002). In the previous section, based on the research of developing a scale to measure the interactivity of websites (Liu, 2003), we explained cross-border $\mathrm{e}^{-} \mathrm{com}^{-}$ merce website interactivity into three dimensions: active control, which describes a users' ability to voluntarily participate in a communication; two-way communication, which corresponds to the bi-directional flow of information; and synchronicity, which refers to the speed of the interaction (Liu, 2003).

Interactivity can be achieved through active 
control. Visitors may be fond of websites on which they can actively control the information flow on the sites and customize the message they receive (Jensen, 1998). If customers have greater control of the shopping experience, their pleasure of shopping will be increased (Marmorstein, Grewal and Fishe, 1992). Similarly, if a cross-border website visitor can have enough control over his or her visiting experience, or if they can choose freely what they want to see on the sites, they may be more satisfied with the site.

Two way communications is especially important to achieve the interactivity in the cross-border e-commerce setting where the website and the visitor might use different languages. So websites with translations and in-local proofreaders, or the ones that understand local terminologies and culture will be more interactive.

Interactivity can refer to situations where real-time feedback is collected from the receivers of a communication channel and is used by the source to modify the message (Straubhaar and LaRose, 1996). A synchronous response may lead to a positive experience for internet users.

Several researchers have recognized the importance of the interactivity on the customer satisfaction or loyalties in e-commerce (e.g. Deighton, 1996: Alba et.al, 1997; Watson, Akselsen, and Pitt, 1998; Srinivasana, Andersona, and Ponnavolub, 2002). According to their research, interactivity of a websites enables a search process that quickly locates a desired product or service for customers, thereby replacing customers' dependence on detailed memory. The interactivity with a good search process increases the perceived value that the consumer places on a business transaction (Alba et. al, 1997). Another reason is the amount of information. Interactivity dramatically increases the amount of information that can be presented to a customer (Deighton, 1996: Watson, Akselsen, and Pitt, 1998). In fact, lack of interactivity is a problem for a majority of e-commerce (Srinivasana, Andersona, and Ponnavolub, 2002).

It is difficult to obtain information from some websites because they provide insufficient amount of product information or have delays in $\mathrm{re}^{-}$ sponding to customer inquiries. Since crossborder e-commerce is subjected to geographic, time, language differences between seller and buyer, domestic e-commerce is slightly more advantageous in achieving synchronous interactivity. Therefore, in cross-border $\mathrm{e}^{-}$-commerce, if an online store successfully manages those predicaments and achieve high level of interactivity, then consumers are likely to exhibit positive attitude toward the site. Therefore we propose,

\section{H2: Perceived interactivity of the Cross-bor- der websites is positively related to con- sumers' satisfaction.}

As we previous mentioned convenience is one of the most important advantages for on- 
line shopping (Bhatnagar et al., 2000). However, online shopping is not superior to the in-store shopping in every aspect of convenience. As Beauchamp and Ponder (2010) noted customer perceived that online shopping is more convenient than in store shopping in term of $\mathrm{ac}^{-}$ cess and search convenient, but not in terms of transaction convenience.

As a form of e-commerce, the convenience is an important motivation for the cross-border e-commerce. As we discussed before, time saving and effort minimization are important drivers for the retail convenience (Etgar, 1978; Kotler and Zaltman, 1971; Seiders et al., 2000, 2005, 2007; Yale and Venkatesh, 1986). Shopping on a cross-border e-commerce can save time and effort by making it easy to purchase foreign merchandises (Kim and Park, 2013). Consumers do not have to physically visit a foreign market to find or buy the merchandise. Instead, they can browse for products and make purchase on online store with negligible time and effort. More of consumers' time and effort are saved in cross-border e-commerce compared to domestic e-commerce.

However, customer's expectation on the convenience in the e-commerce is also high. For example, in terms of access convenience, Jiang and Rosenbloom (2005) found out that 73 percent of e-customers will leave an internet page and/or site if it takes more than two to three clicks to get to where they want. In terms of the search convenience, Schaffer (2000) re- ported, $30 \%$ of the consumers leave a website without purchasing anything because they are unable to find their way through the site. Language barrier in the cross-border e-commerce also harms the search convenience as it prevents customers from requesting right searches, reading the product specifications, and receiving appropriate product recommendations. Also, Beauchamp and Ponder (2010) pointed out that customers experience inconvenience regarding the transaction methods in the e-commerce. Since the convenience is a major reason for the customer to shop through cross-border e-commerce (Han and Chen, 2012) if it overcomes these obstacles and provides shopping convenience, it will experience positive post purchase attitudes of its customers. Thus, we propose that
H3: Convenience of the Cross-border web- sites is positively related to consumers' satisfaction.

In the traditional off line marketing setting, a large number of researchers proved the direct link between customer satisfaction and customer loyalty (e.g. Rust and Zahoric (1994); Anderson, Fornell and Lehmann (1994); Hallowell (1996)). The positive relationship between the satisfaction and the loyalty is also supported in the retail setting. (e.g. Gassenheimer, Sterling, and Robicheaux, 1989; Ping, 1993). Customers experiencing a high level of satisfaction are 
likely to remain with the same product or the same stores. Compared to a satisfied consumer, those who are dissatisfied with a brand or a product is more likely to search for other information on alternatives and more likely to yield to competitor (Anderson and Sullivan, 1993).

In the line of previous argument to explain the relationship between satisfaction and loyalty, the link between customer satisfaction and customer loyalty in the e-commerce setting is also investigated and proved to be positive. Satisfied customers are more likely to continue their purchase behavior and be willing to develop relationships with the websites which can fulfill the agreed conditions ( $\mathrm{Li}$ and Zhang, 2002). Nguyen (2015) showed that if the customers were more satisfied with the service or products offered by the website, the level of customers' loyalty would be higher and the chance of customers repeat purchase would be also higher. However, if the customers are dissatisfied, they are more likely to switch to other websites that can satisfy them ( $\mathrm{Lin}$ and Lu, 2000). Moreover, decrease in satisfaction level will lead to greater decrease in loyalty (Yoon and Kim, 2000). Several other studies have confirmed that the relationship between satisfaction and loyalty in $\mathrm{e}^{-}$-commerce is positive (Chang and Wang, 2008; Sahadev and Purani, 2008; Chiou et al., 2009; Kim et al., 2009, Ribbink et al., 2009).

Cross-border e-commerce involves more risks than does the domestic e-commerce in terms of product delivery, payment option, and the product authenticity. In other words, consumers would rather establish a long-term relationship with an online store if they are satisfied by the goods and services provided than take risks to search for another online store. This may indicate that satisfaction plays more influential role in cross-border e-commerce than in domestic e-commerce. Thus we predict,

H4: The level of satisfaction on websites is positively related to the level of loyalty on the websites.

\section{Research Method}

\subsection{Questionnaire and sampling}

In order to test the hypotheses on the crossborder e-commerce, a survey was conducted. The questionnaire consisted of an opening instruction page that asked the respondents to write one of the cross-border websites they have used before. Respondents were then instructed to answer all the following questions based on their experiences with the website. Items to measure the construct were adapted from extant literatures. Respondents were asked to mark their responses to each questions using the 1 to 7 Likert type scales on which the anchor for 1was "strongly disagree" and for 7 
"strongly agree".

Pilot test, sample size of 40 , was conducted to eliminate some of questions that inflicted internal consistency of a construct. The final version of the questionnaire consisted of 39 items. A detailed description on the items are shown in Table below and Appendix I

Website trustworthiness was measured by fifteen items that captured four dimensions: 1) Websites' security assurance 2) product quality, 3) delivery service and 4) size \& reputation. Websites' security assurance was measured by a three- item scale which was developed by Park and Kang (2000), three items to measure Product quality and two items to measure Delivery service were adapted from Ahn and colleagues (2007). Finally, four items about websites' size \& reputation adapted from Jarvenpaa and his colleagues (2000). Size and reputation had high correlation in that research and we also found strong relationship between size and reputation. Following Jarvenpaa and his colleagues (2000), we decided to consider those two measures as a single construct. (We do have result with separating this construct to "size" and "reputation". However as a first order construct, it does not produce different result on the second order model)). Interactivity was measured by 10 items that captured three dimensions; active control (3 items), two way communication (4 items), Synchronicity (3 items). All the items were adapted from Liu (2003). Convenience was measured by nine items that were adapted from Seiders and colleagues (2007) to capture three dimensions: access convenience (3 items), benefit convenience (3 items), transaction convenience (3 items). Three items were used for measuring satisfaction were adapted from Oliver (1980) and the Loyalty was measured by five items which based on Anderson and Sullivan (1993).

A convenient sample of 403 subjects (200 Korean respondents and 203 Chinese respondents) was collected. The sample was comprised of 208 males and 195 females. In terms of age, 339 were between 20 and 30, 45 were between 30 and 40, 14 were between 40 and 50. Both samples show similar distribution in terms of demographics

\subsection{Second-order factor analysis}

Our conceptual model was test by the second order PLS modeling with two step approaches. While the hierarchical component approach is easier to estimate and popular, two-step approach is a more rigorous method than hierarchical components approach (Chin, 1998). In this approach, we firstly obtained "latent variables scores" for first-order latent variables in the first-order construct PLS path analysis, and then these latent variables are used as manifest variables for second-order variables.

In this research, we have a reflectivereflective type measurement model, the indicators (questionnaire items) are operational- 
ized as reflective relationship between the firstorder component (i.e., security assurance, product quality, delivery service, size \& reputation) and second-order components (i.e., trustworthiness, convenience, interactivity). Firstly, we constructed 10 first-order variables (security, delivery, product, size, Active, Two way, synchronicity, Access, Transaction, Benefit) and related them to their respective block of 31 manifest variables. And then, second-order latent variables (reliability, interactivity, convenience) were constructed by using the analysis results of the latent variable scores for first-order variables as manifest variable for second-order variables. After running the algorithm, the "Latent variable scores" of first-order model in the output under PLS - Calculation results can be found. In the second stage, we used those scores as the indicators for secondorder variables and ran the algorithm again to test the structural model.

\section{Results and Findings}

First, we dropped indicators if they do not meet the validity and reliability requirements of $\mathrm{re}^{-}$ flective measure model. To be more specific, if an item has $<0.60$ score on a factor loading table, it must be eliminated since small value indicates that the item has less contribution to the latent factor.

\subsection{Results of first-order model}

For the internal consistency reliability of the first order construct, we calculated the composite reliability of the construct. The values of all the constructs are above 0.7, which indicates a high individual reliability of each variable (Nunally and Bernstein, 1994). For the discriminant validity, we used the Fornell-Larcker criterion assessment (Fornell and Larcker, 1981) which compares the square root of the average variance extracted (AVE) of a latent variable with correlations between the latent variable and other latent variables. Overall, the square roots of the AVEs for the constructs are all higher than the correlations of these constructs with other latent variables, which explained a higher discriminant validity in the path model To assess the model fit, we ran the blindfolding procedure to assess the predictive relevance of the model, as shown in table 1 . Redundancy values of endogenous constructs (i.e., satisfactory, loyalty) are above zero, providing support for the model's predictive relevance (Chin, 1998). R Squares were greater than 0.26, showing a high model fit (Cohen, 1988).

The overall measurement of model fit can be evaluated by Goodness of Fit (Mulaik et al.,, 1989). Tenenhaus and colleagues, (2005) evaluated that if the value of Goodness of Fit is above 0.36, it means a high model fit, we calculated that first-order model's GOF (0.659) was above 0.36 , so it showed a good model fit as 
well in the first-order model (shown in table 1).

The value of Goodness of Fit

$$
=\sqrt{\overline{\text { Communality }} \times \overline{R^{2}}}
$$

\subsection{Results of second-order construct model}

\subsubsection{Internal consistency reliability}

Results of "the latent variable scores" for first-order variables were used as manifest variable for second-order variables. The findings of results have been presented from table 2 to table 5. Outcomes of second-order constructs and the significant value $\mathrm{p}$-value were shown after having bootstrapping.

Table 2 shows that Composite reliability and
AVEs of the measures in the second-order models. The values of Composite reliability were all above 0.80 and AVE greater than 0.65, which is evidence that measures are reliable.

As demonstrated in table3, the loadings of the first-order latent variables on the secondorder factors exceed 0.8 , which are in support of the second-order model of validity. The results indicate that all loadings are significant at $\mathrm{p}=0.00$

\subsubsection{Discriminant validity}

Moreover, as shown in table 4, the square root of the AVE exceeds the intercorrelations of the construct with the other constructs in the model, in support of discriminant validity (Fornell and Larcker, 1981).

〈Table 1〉 First-order model's GOF

\begin{tabular}{|l|l|}
\hline$\overline{\text { Communality }}$ & $\begin{array}{l}(0.743+0.651+0.678+0.682+0.733+0.615+0.815+0.656+0.709+0.702 \\
+0.785+0.606) / 12=0.698\end{array}$ \\
\hline$\overline{R^{2}}$ & $(0.623+0.623) / 2=0.623$ \\
\hline GOF & $\sqrt{ } 0.698 \times 0.623=0.659$ \\
\hline
\end{tabular}

〈Table 2〉 Internal Consistency reliability

\begin{tabular}{|c|c|c|c|c|c|c|}
\hline & $\begin{array}{c}\text { Composite } \\
\text { Reliability }\end{array}$ & $\begin{array}{c}\text { Cronbachs } \\
\text { Alpha }\end{array}$ & Communality & AVE & Redundancy & R Square \\
\hline Trust & 0.883 & 0.823 & 0.654 & 0.654 & & \\
\hline Inter & 0.911 & 0.853 & 0.773 & 0.773 & & \\
\hline Con & 0.891 & 0.817 & 0.731 & 0.731 & & \\
\hline Sat & 0.930 & 0.886 & 0.815 & 0.815 & 0.500 & 0.616 \\
\hline Loy & 0.932 & 0.909 & 0.733 & 0.733 & 0.454 & 0.623 \\
\hline
\end{tabular}

*Note: trustworthiness (Trust), interactivity (Inter), convenience (Con), satisfaction (Sat), loyalty (Loy) 
〈Table 3〉 Outer loadings2

\begin{tabular}{|c|c|c|c|c|c|c|}
\hline & Trust & Inter & Con & Loy & Sat & $\mathrm{P}$ Values \\
\hline $\mathrm{Sec}$ & 0.871 & & & & & 0.000 \\
\hline Size & 0.813 & & & & & 0.000 \\
\hline Qua & 0.804 & & & & & 0.000 \\
\hline Deli & 0.742 & & & & & 0.000 \\
\hline Act & & 0.868 & & & & 0.000 \\
\hline Twa & & 0.878 & & & & 0.000 \\
\hline Syc & & 0.891 & & & & 0.000 \\
\hline Tra & & & 0.874 & & & 0.000 \\
\hline Acc & & & 0.819 & & & 0.000 \\
\hline Ben & & & 0.871 & & & 0.000 \\
\hline Sat1 & & & & & 0.873 & 0.000 \\
\hline Sat2 & & & & & 0.904 & 0.000 \\
\hline Sat3 & & & & & 0.932 & 0.000 \\
\hline Loy1 & & & & 0.854 & & 0.000 \\
\hline Loy2 & & & & 0.856 & & 0.000 \\
\hline Loy3 & & & & 0.864 & & 0.000 \\
\hline Loy4 & & & & 0.877 & & 0.000 \\
\hline Loy5 & & & & 0.830 & & 0.000 \\
\hline
\end{tabular}

〈Table 4〉 Discriminant validity: Fornell-Larker Criterion

\begin{tabular}{|c|c|c|c|c|c|}
\hline & Trust & Inter & Con & Sat & Loy \\
\hline Trust & 0.809 & & & & \\
\hline Inter & 0.748 & 0.879 & & & \\
\hline Con & 0.772 & 0.764 & 0.855 & & \\
\hline Sat & 0.707 & 0.688 & 0.751 & 0.903 & \\
\hline Loy & 0.630 & 0.662 & 0.631 & 0.790 & 0.856 \\
\hline
\end{tabular}

*Note: trustworthiness (Trust), interactivity (Inter), convenience (Con), satisfaction (Sat), loyalty (Loy)

\subsubsection{Second-order model fit}

Redundancy values of endogenous constructs (i.e., satisfactory, loyalty) showed in table 2, which is in support of the structural model's quality (Chin, 1998). GOF 0.678 as in the table 5 showed a good model fit. 
〈Table 5〉 Second-order model's GOF

\begin{tabular}{|l|l|}
\hline$\overline{\text { Communality }}$ & $(0.731+0.773+0.654+0.815+0.733) / 5=0.741$ \\
\hline$\overline{R^{2}}$ & $0.616+0.623) \quad / 2=0.620$ \\
\hline GOF & $\sqrt{ } 0.741 \times 0.620=0.678$ \\
\hline
\end{tabular}

$\langle$ Table 6〉 path coefficients and t-values for total samples

\begin{tabular}{|c|c|c|c|c|}
\hline & path coefficient & se & $\mathrm{p}$ Values & Hypothesis test \\
\hline Trust $\rightarrow$ Sat & 0.245 & 0.060 & 0.000 & H1 supported \\
\hline Inter $\rightarrow$ Sat & 0.181 & 0.074 & 0.015 & H2 supported \\
\hline Con $\rightarrow$ Sat & 0.424 & 0.068 & 0.000 & H3 supported \\
\hline Sat $\rightarrow$ Loy & 0.790 & 0.029 & 0.000 & H4 supported \\
\hline
\end{tabular}

*Note: trustworthiness (Trust), interactivity (Inter), convenience (Con), satisfaction (Sat), Loyalty(Loy)

\subsection{Hypotheses test}

Finally, we present the results of path $\mathrm{co}^{-}$ efficient between variables in table 6. Path models are used to test the hypotheses. As usual, we calculated $\mathrm{p}$-values by using the bootstrapping technique. Bootstrapping with 500 resamples was used in order to test path significance.

Table 6 contains the coefficients and t-values for the total samples. The independent variables trustworthiness $(\gamma)=0.245, \mathrm{P}=0.000)$, interactivity $(\gamma=0.181, P=0.015)$, convenience $(\gamma=0.424, \mathrm{P}=0.000)$ all have significant positive relationships with consumers' satisfaction, and consumer satisfaction is significantly positively related to consumer loyalty $(\beta=0.790$, $\mathrm{P}=0.000$ ), which supported our Hypothesis 1 , Hypothesis 2, Hypothesis 3, Hypothesis 4.

Furthermore, we tested the differences among the path of independent variables (website trustworthiness, interactivity, convenience) to consumer satisfaction. The significance of the difference between path coefficients was examined by performing an unpaired t-test, based on estimates and standard errors generated by bootstrapping suggested by Keil et. al. (2000). Thus the t-statistics to compare the path coefficient is as follows

$$
\begin{aligned}
& \mathrm{t}=\frac{\gamma^{(1)}-\gamma^{(2)}}{\sqrt{\frac{\left(n^{(1)}-1\right)^{2}}{n^{(1)}+n^{(2)}-2} \operatorname{se}\left(\gamma^{(1)}\right)^{2}+\frac{\left(n^{(2)}-1\right)^{2}}{n^{(1)}+n^{(2)}-2} \operatorname{se}\left(\gamma^{(2)}\right)^{2}} \sqrt{\frac{1}{n^{(1)}}+\frac{1}{n^{(2)}}}} \\
& \begin{array}{ll}
n & : \text { sizes of subsamples } \\
n^{(1)}+n^{(2)}-2 & : \text { degree of freedom } \\
& \quad: \text { subsample specific path coefficients } \\
\text { se } & : \text { path coefficient standard errors }
\end{array}
\end{aligned}
$$

t-values are shown in table 7 . Results showed that impact of convenience to satisfaction was 
〈Table 7〉 Differences of path coefficients in total samples

\begin{tabular}{|c|c|c|c|}
\hline & path coefficient & se & t-Value \\
\cline { 1 - 3 } & 0.245 & 0.06 & \multirow{2}{*}{0.67} \\
\hline Trust $\rightarrow$ Sat & 0.181 & 0.074 & Sat \\
\hline
\end{tabular}

\begin{tabular}{|c|c|c|c|}
\hline & path coefficient & se & t-Value \\
\hline Trust $\rightarrow$ Sat & 0.245 & 0.06 & \multirow{2}{*}{-1.985} \\
\hline Con $\rightarrow$ Sat & 0.424 & 0.068 & \\
\hline
\end{tabular}

\begin{tabular}{|c|c|c|c|}
\hline & path coefficient & se & t-Value \\
\cline { 1 - 3 } & 0.181 & 0.074 & \multirow{2}{*}{-2.419} \\
\hline Inter $\rightarrow$ Sat & 0.424 & 0.068 & \\
\hline
\end{tabular}

*Note: trustworthiness (Trust), interactivity (Inter), convenience (Con), satisfaction (Sat)

greater than that of trustworthiness to satisfaction. (difference $=0.179, \mathrm{t}=1.985$ ), and the impact of convenience to satisfaction was greater than that of interactivity to satisfaction. (difference $=0.243, \mathrm{t}=2.419)$ while there was no statistically significant difference between trustworthiness to satisfaction path and interactivity to satisfaction path (difference $=0.064, t=0.670$ ) .

We conclude that among website trustworthiness, website convenience and website interactivity, website convenience is the most important predictor of consumer satisfaction.

\subsection{Comparative study}

The results from the whole sample (Korean sample and Chinese sample) show that convenience is the most powerful influencer of the customer satisfaction in the cross-border $\mathrm{e}^{-}$ commerce among three factors. In order to find out possible differences between the two coun- tries, we conducted a comparative study between Korean and Chinese respondents. First, we conducted PLS Algorithm within groups and calculated $t$-values based on the formula described by (Keil et al., 2000). Results derived from Korean sample were shown in table 8. The website convenience $(\gamma=0.340, \mathrm{p}=0.001)$ and trustworthiness $(\gamma=0.285, \mathrm{p}=0.001)$ is positively related to satisfaction, while interactivity to satisfaction path was not statistically significant $(\gamma=0.148, p=0.157)$. In the Korean group, we cannot say that one antecedent has stronger influence than the other antecedent in the pairwise comparison base at significant level of 0.10 .

However, Chinese sample tells us a different story. In the Chinese sample, all three of factors; website convenience $(\gamma=0.487, \mathrm{p}=0.000)$, interactivity $(\gamma=0.225, \mathrm{p}=0.018)$ and trustworthiness $(\gamma=0.195, \mathrm{p}=0.012)$ are positively related to satisfaction. Moreover, in Chinese 
〈Table 8〉 Differences within Korea Group

\begin{tabular}{|c|c|c|c|}
\hline Korea & path coefficients & se & t-value \\
\hline Trust $\rightarrow$ Sat & 0.285 & 0.089 & \multirow{2}{*}{1.001} \\
\hline Inter $\rightarrow$ Sat & 0.148 & 0.105 & \\
\hline
\end{tabular}

\begin{tabular}{|c|c|c|c|}
\hline Korea & path coefficients & se & t-value \\
\hline Trust $\rightarrow$ Sat & 0.285 & 0.089 & \multirow{2}{*}{-0.400} \\
\hline Con $\rightarrow$ Sat & 0.34 & 0.105 & \\
\hline
\end{tabular}

\begin{tabular}{|c|c|c|c|}
\hline Korea & path coefficients & se & t-value \\
\hline Inter $\rightarrow$ Sat & 0.148 & 0.105 & \multirow{2}{*}{-1.294} \\
\hline Con $\rightarrow$ Sat & 0.34 & 0.105 & \\
\hline
\end{tabular}

*Note: trustworthiness (Trust), interactivity (Inter), convenience (Con), satisfaction (Sat)

sample, convenience to satisfaction path has a stronger influence than does interactivity to VI. Conclusion satisfaction path (difference $=0.262, t=2.042$ ). The path form convenience to satisfaction is In spite of growing popularity of cross-border also stronger than that from trustworthiness to satisfaction (difference $=0.292, t=2.527$ ), while the path from interactivity and trustworthiness to satisfaction has no statistically significant difference (difference $=0.03, t=0.248$ ). e-commerce, only a few research has been conducted in this area. This research provides couple of theoretical and managerial contributions to the e-commerce literature and industry. First, by relying on the current research in the

$\langle$ Table 9〉 Differences within China Group

\begin{tabular}{|c|c|c|c|}
\hline China & path coefficients & se & t-value \\
\hline Trust $\rightarrow$ Sat & 0.195 & 0.078 & \multirow{2}{*}{-0.248} \\
\hline Inter $\rightarrow$ Sat & 0.225 & 0.095 & \\
\hline
\end{tabular}

\begin{tabular}{|c|c|c|c|}
\hline China & path coefficients & se & t-value \\
\hline Trust $\rightarrow$ Sat & 0.195 & 0.078 & \multirow{2}{*}{-2.527} \\
\hline Con $\rightarrow$ Sat & 0.487 & 0.086 & \\
\hline
\end{tabular}

\begin{tabular}{|c|c|c|c|}
\hline China & path coefficients & se & t-value \\
\hline Inter $\rightarrow$ Sat & 0.225 & 0.095 & -2.042 \\
\hline Con $\rightarrow$ Sat & 0.487 & 0.086 & \\
\hline
\end{tabular}

*Note: trustworthiness (Trust), interactivity (Inter), convenience (Con), satisfaction (Sat), loyalty (Loy) 
electronic commerce and general marketing we identified key antecedents of customer satisfaction to the customer satisfaction in the cross-border e-commerce (i.e., trustworthiness, interactivity and convenience). Results from the pooled data show that convenience is the most important antecedent in the cross-border e commerce. The results reassure that most of online customers are convenience oriented (see, Constantinides, 2004; Donthu and Garcia, 1999; Korganonkar and Wolin, 1999) in the cross-border e-commerce case. Second, important sub dimensions of those antecedents (i.e., security assurance; active control; access convenience; etc.) are proposed and test by using second order PLS. Third, although it was limited to two countries, we compared the strength of the path from each antecedent to satisfaction in each country. Chinese consumers consider convenience to be more important factor over interactivity and trustworthiness in cross-border purchasing, while Korean consumers did not exhibit such difference among factors. Although the results is from the comparison of two countries the finding provides meaningful managerial insight. When the cross-border e-commerce company targets multiple segments of consumers in foreign countries at the same, it may have to focus on different attribute of the service for the customers from different culture or countries.

Although this research discovered significance of some website traits and to which degree they have positive influence over consumer satisfaction and loyalty, it still has some limitations.

First, sampling methods in both countries is a convenient sampling, which results in limited generalizability of the results. Second, since our attempt to conduct a comparative study between Korean and China is in an explorative manner, we could not derive an adequate and thorough explanation for the differences between Chinese and Korean consumers. Intensive censorship in China, in some ways, does explain why Chinese consumers are more interested in convenience of online store compared to Korea. However, we cannot neglect the possibilities that there are more fundamental reasons beneath such difference. Third, not all plausible candidates for influential antecedents to e-satisfaction, such as website-design (or other factors more related to cultural differences), have been examined in this study. Fourth, the results could have been more meaningful if the data regarding non cross-border e-commerce are collected and compared with cross-border

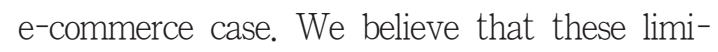
tations provide good opportunities for the future research.

〈Received July 8. 2016〉

〈Revised August 8. 2016〉

〈Accepted August 9. 2016〉 


\section{References}

Ahmad, Sohel. (2002), "Service Failures and Customer Defection: a Closer Look at Online Shopping Experiences," Managing Service Quality, 12(1), 19-29.

Ahn, Tony, Seewon Ryu, and Ingoo Han(2007), "The Impact of Web Quality and Playfulness on User Acceptance of Online $\mathrm{Re}^{-}$ tailing," Information \& Management, 44(3), 263-275.

Alba, Joseph, John Lynch, Barton Weitz, Chris Janiszewski, Richard Lutz, Alan Sawyer, and Stacy Wood (1997), "Interactive Home shopping: Consumer, Retailer., Manufacturer and Incentives to Participate in Electronic Marketplaces," Journal of Marketing, 61(3), 38-53.

Anderson, Eugene W. and Mary W. Sullivan (1993), "The Antecedents and Consequences of Customer Satisfaction for Firms," $\mathrm{Ma}^{-}$ nagement Science, 12(2), 125-143.

- Cales Fornell, and Donald R. Lehmann (1994), "Customer Satisfaction, Market Share, and Profitability: Findings from Sweden," Journal of Marketing, 58 (3), 53-66.

Assael, Henry (1992), “Consumer Behavior and Marketing Action $4^{\text {th }}$ Edition," Boston: PWS-Kent.

Back, Yongme (2013), “25\% Online Shopper Uses Cross-border shopping mall," (accessed
Augest 5, 2013), [available at http:// www.newsis.com/ar_detail/view.html? ar_id $=$ NISX20130802_0012265517\&cID = $10401 \& \mathrm{pID}=10400]$.

Balasubramanian, Sridhar, Prabhudev Konana, and Nirup M. Menon (2003), "Customer Satisfaction in Virtual Environments: A Study of Online Investing," Management Science, 49(7), 871-889.

Bearden, William O. and Jesse E. Teel (1983), "Selected Determinants of Consumers Satisfaction and Complaint Reports," Journal of Marketing Research, 20(1), 21-28.

Beauchamp, Michelle B. and Nicole Ponder (2010), "Perceptions of Retail Convenience for In-store and Online Shoppers," The Marketing Management Journal, 20(1), 49-65.

Belanger, France, Janine S. Hiller, and Wanda J. Smith (2002), "Trustworthiness in Electronic Commerce: the Role of Privacy, Security, and Site Attributes," The Journal of Strategic Information Systems. 11(3-4), 245-270.

Berry, Leonard L., Kathleen Seiders, and Dhruv Grewal (2002), "Understanding Service Convenience," Journal of Marketing, 66(3), 1-17.

Bezjian Avery, Alexa, Bobby Calder, and Dawn Iacobucci (1998), “New Media Interactive Advertising vs Traditional Advertising," Journal of Advertising Research, 38 (4), 23-32.

Bhatnagar, Amit, Sanjog Misra, and H Raghav 
Rao (2000), "On Risk, Convenience and Internet Shopping Behavior," Communications of the ACM, 43(11), 98-105.

Bitner, Mary J., Bernerd H. Booms, and Mary S. Tetreault (1990), "The Service Encounter: Diagnosing Favorable and Unfavorable Incidents," Journal of Marketing, 54(1), 71-84.

Blattberg, Robert C. and John Deighton (1991), "Interactive Marketing: Exploiting the Age of Addressibility," MIT Sloan Management, 33(1), 5-14.

Bollen, Kenneth A. and Richard D. Lennox (1991), "Conventional Wisdom on Measurement: A Structural Equation Perspective," Psychological Bulletin, 110(2), 305-314.

Chang, Hsin H., Yao H. Wang, and Wen Y. Yang (2009), "The Impact of E-service Quality, Customer Satisfaction and Loyalty on E-marketing: Moderating Effect of Perceived Value," Total Quality Management \& Business Exellence, 20(4), 423-443. and Su Wen Chen (2009), "Consumer Perception of Interface Quality, Security, and Loyalty in Electronic Commerce," Information and Management, 46(7), 411-417. Chin, Wynne W.(1998), “Commentary: Issues and Opinion on Structural Equation Modeling," MIS Quarterly, 22 (1), 7-16.

Chiles, Todd H. and John F. McMackin (1996), "Integrating Variable Risk Preferences, Trust, and Transaction Cost Economics," The Academy of Management Review, 21(1), 7399.

86 ASIA MARKETING JOURNAL Vol. 18 No. 02 July 2016
Chiou, J.Shen, Lei-Yu Wu, and Yi-Ping Sung (2009), "Buyer Satisfaction and Loyalty Intention in Online Auctions: Online Auction Website versus Online Auction Seller," Journal of Service Management, 20(5), 521-543.

Choi, Nakgyoon (2012), "Impacts and Main Issues of the Korea-China FTA," Research Report, Korea Economic Institute of America.

Choi, Sejung M. and Nora J. Rifon (2002), "Antecedents and Consequences of Web Advertising Credibility: A study of Consumer Response to Banner Ads," Journal of Interactive Advertising, 3(1), 12-24.

Chow, Simeon and Reed Holden (1997), "Toward an understanding of loyalty: The Moderating Role of Trust," Journal of Managerial Issues, 9(3), 275-298.

Civic Consulting (2011), "Consumer Market Study on the Functioning of E-commerce and Internet Marketing and Selling Techniques in the Retail of Goods," Research Report, Civic Consulting, (September 9).

Cohen, Jacob (1988), "Statistical Power Analysis for the Behavioral Sciences 2nd Edition," Hillsdale, New Jersey: Lawrence Erlbaum. Constantinides, Efthymios (2004), "Influencing the Online Consumer's Behavior: the Web Experience," Internet Research, 14(2), 111126.

Copeland, Melvin T. (1923), "Relation of consumer's buying habits to marketing method," Harvard Business Review, 1(3), 282-289.

Damanpour, Faramarz and Jamshid A. Damanpour 
(2001), "E-business E-commerce Evolution: Perspective and Strategy," Managerial Finance, 27(7), 16-33.

Deighton, John (1996), "The Future of Interactive Marketing," Harvard Business Review, 74(6), 151-160.

Del Duca, LouisF., Colin Rule, and Zbynek Loebl (2011), "Facilitating Expansion of Cross-Border E-Commerce-Developing a Global Online Dispute Resolution System (Lessons Derived from Existing ODR Systems - Work of the United Nations Commission on International Trade Law," Penn State Journal of Law \& International Affairs, 1(1) 59-85.

Doney, Patricia M. and Joseph P. Cannon (1997), "An Examination of the Nature of Trust in Buyer-Seller Relationships," Journal of Managerial, 60(2), 35-51.

Donthu, Naveen and Adriana Garcia (1999), "The Internet Shopper," Journal of Advertising Research, 39(3), 52-58.

Etgar, Michael (1978), "Differences in the Use of Manufacturer Power in Conventional and Contractual Channels," Journal of Retailing, 54, 49-62.

European Commission (2013), "Retailers Attitudes towards Cross-border Trade and Consumer Protection," Report of Flash Eurobabarometer 359.

Feinberg, Richard and Rajesh Kadam (2002), "E-CRM Web Service Attributes as Determinants of Customer Satisfaction with
Retail Web Sites," International Journal of Service Management, 13(5), 432-451.

Fiore, Ann M., Hyun-Jeong Jin and Jihyun Kim (2005), "For Fun and Profit: Hedonic Value from Image Interactivity and $\mathrm{Re}^{-}$ sponses toward an Online Store," Psychology \& Marketing, 22(8), 669-694.

Fornell, Claes and David F. Larcker (1981), Evaluating Structural Equation Models with Unobservable Variables and Measurement Error," Journal of Marketing Research, 18 (1), 39-50.

Gassenheimer,Sterling and Robicheaux (1989), "Long-term Channel Member Relationships," International Journal of Physical Distribution and Materials Management, 19 (12), 15-28.

Gomez-Herrera, Estrella, Bertin Martens1, Geomina Turlea (2014), "The Drivers and Impediments for Cross-border E-commerce in the EU," Information Economics and Policy, 28(C), 83-96.

Hallowell, Roger (1996), “The Relationships of Customer Satisfaction, Customer loyalty, and Profitability: an empirical study," International Journal of Service Industry Management, 7(4), 27-42.

Han, Xiu and Liang Chen (2012), "Chinese People Consumed Near 300billion RMB in Overseas High-graded Commidities," (accessed September 9, 2012), [available at http:// www.hinews.cn/news/system/2012/09/09/ 014927914.shtml]. 
Hoffman, Donna L., Thomas P. Novak, and Marcos Peralta (1999), "Building Consumer Trust in Online Environments: The Case for Information Privacy," Communications of the ACM, 42(4),80-85.

Huizingh, Eelko K. R. E (2000), “The Content and Design of Web Sites: An Empirical Study," Information and Management, 37 (3), 123-134.

Human Rights Watch (2006), "How Censorship Works in China: A Brief Overview," (accessed Augest 8), [available at http://www. hrw.org/reports/2006/china0806/3.htm].

Jacoby,Jacob (1971), “A Model of Multi-Brand Loyalty," Journal of Advertising Research, 11(3), 25-30.

Jarvenpaa, Sirkka L., Noam Tractinsky, and Michael Vitale (2000), "Consumer Trust in an Internet Store," Information Technology and Management; 1(1-2), 45-71.

Jayawardhena, Chanaka, Len T. Wright, and Charles Dennis (2007), "Consumers Online: Intentions, Orientations and Segmentation," International Journal of Retail \& Distribution Management, 35(6), 515-526.

Jensen, Jens F. (1998), "Interactivity: Tracing a New Concept in Media and Communication Studies," Nordicom Review, 19 (1), 185-204.

Jiang, Pingjun and Bert Rosenbloom (2005), "Customer Intention to Return Online: Price Perception, Attribute Level Performance, and Satisfaction Unfolding Over
Time," European Journal of Marketing, 39 (1), 150-174.

Jiang,Ling, Zhilin Yang and Minjoon Jun (2012), "Measuring Consumer Perceptions of online Shopping Convenience," Journal of Service Management, 24(2), 191-214.

Keeney, Ralph L. (1999), “The Value of Internet Commerce to the Customer," Management Science, 45(4), 533-542.

Keil, Mark, Bernard C. Y. Tan, Kwok-Kee Wei, Timo Saarinen, Virpi Tuunainen, and Arjen Wassenaar (2000), “A Cross-Cultural Study on Escalation of Commitment Behavior in Software Projects," Management Information Systems Quarterly, 24(2), 299325.

Keller, Kevin L. (1993), "Conceptualizing, Measuring, and Managing Customer-Based Brand Equity," Journal of Marketing, 57(1), 1-22. Kim, Hyo J. (2014), "Cross Border Shopping Mall, "iHerb'got Highest Score," (accessed Augest 7, 2014), [available at http:// www.hani.co.kr/arti/economy/economy_ general/650216.html].

Kim, J. D., and Park, P.J. (2013), "Is CrossBorder E-commerce Silk Road or Mirage? Korea International Trade Association," 12 (40), 1-17.

Kim, Hee-Woong, Yunjie Xu, and Joon Koh (2004), “A Comparison of Online Trust Building Factors between Potential Customers and Repeat Customers." Journal of the Association for Information Systems, 
5(10), 392-420.

Kongaonkar, Pradeep and Wolin, Lori D. (1999),

"A Multivariate Analysis of Web-Usage," Journal of Advertising Research, 39(2), 53-68.

Kotler, Philip and Gerald Zaltman (1971), "Social Marketing: An Approach to Planned Social Change," Journal of Marketing, 35(3), 3-12.

Kumar, Piyush, Manohar U. Kalwani, and Maqbool Dada (1997), “The Impact of Waiting Time Guarantees on Consumer Waiting Experiences," Marketing Science, 16(4), 295-314.

Laudon, Kenneth C. and Jane P. Laudon (2012), "Essentials of Management Information Systems (10th ed.)," Boston: Pearson.

Lee, Hyo J. (2013), “Housewife Kim, Money Saved through Cross-boarder E-commerce," (accessed December 23, 2013), [available at http://www.econovill.com/archives/143420].

Li, Na and Ping Zhang (2002), "Consumer Online Shopping Attitudes and Behavior: An Assessment of Research," Proceedings of the Americas Conference on Information Systems, 508-517 (Augest 9-11).

Lin, Judy C. and Hsipeng Lu (2000), “Towards an Understanding of the Behavioural Intention to Use a Web Site," International Journal of Information Management, 20(3), 197-208.

Liu, Yuping (2003), "Developing a Scale to Measure the Interactivity of Websites," Journal of Advertising Research, 43(2),
207-216

Liu, Yuping and L.J. Shrum (2002), "What is Interactivity and is It Always Such a Good Thing? Implications of Definition, Person, and Situation for the Influence of Interactivity on Advertising Effectiveness," Journal of Advertising, 31(4), 53-64.

Marmorstein, Howard, Dhruv Grewal, and Raymond P.H. Fishe (1992), “The Value of Time Spent in Price-Comparison Shopping: Survey and Experimental Evidence," Journal of Consumer Research, 19 (1), 52-61.

McDermott, Keira (2015), “Key Business Drivers and Opportunities in Cross-border Ecommerce, Entering an Omnichannel World, 2015," Research report, Payvision Global Card Processing.

McMillan, Sally J. and Jang-sun Hwang (2002), "Measures of Perceived Interactivity: An Exploration of the Role of Direction of Communication, User Control, and Time in Shaping Perceptions of Interactivity," Journal of Advertising, 31(3), 29-42.

Meuter, Matthew L., Amy L. Ostrom, Robert I. Roundtree, Mary Jo Bitner (2000), "SelfService Technologies: Understanding Customer Satisfaction with Technology-Based Service Encounters," Journal of Marketing, 64(3), 50-64.

Moorman, Christine, Rohit Deshpande and Gerald Zaltman (1993), "Factors Affecting Trust in Market Research Relationships," Journal 
of Marketing, 57(1), 81-101.

Morgan, Robert M. and Shelby D. Hunt (1994), "The Commitment-Trust Theory of Relationship Marketing," Journal of Marketing, 58(3), 20-38.

Morganosky, Michelle A. and Brenda J. Cude (2000), "Consumer Response to Online Grocery Shopping," International Journal of Retail \& Distribution Management, 28(1), 17-26.

Mulaik, Stanley A., Larry R. James, Judith Van Alstine, Nathan Bennett, Sherri Lind, and Dean Stilwell (1989), "Evaluation of Goodness of Fit Indicies for Structural Equation Model," Psychological Bulletin, 105(3), 430-445.

Nguyen, Binh (2015)," Customer's Satisfaction and Loyalty through E-commerce: The Case of Company X," Bachelor's Dissertation, Department of Financial Management, Tampere University of Applied Sciences.

Nunally, Jum C. and Ira H. Bernstein (1994), "Psychometric theory," New York: McGrawHill.

Oliver, Richard L. (1980), “A Cognitive Model of Antecedents and Consequences of $\mathrm{Sa}^{-}$ tisfaction Decisions," Journal of Marketing Research, 17(4), 460-469.

Palmer, Jonathan W. (2000), "Web Site Usability, Design, and Performance Metrics," Information Systems Research, 13(2), 151167.

Park, Chul and Byeungku Kang (2000), "Factors
Influencing on Consumer Trust toward Internet Shopping Mall," The Korea Society of Management information Systems, 7(5) 869-879.

Pavlik, John V. (1998), "New Media Technology: Cultural and Commercial Perspectives," 2nd Edition, Boston: Allyn and Bacon.

Ping, Robert A. Jr. (1993), "The Effects of Satisfaction and Structural Constraints on Retailer Exiting, Voice, Loyalty, Opportunism, and Neglect," Journal of Retailing, 69 (3), 320-352.

Punj, Girish and Robert Moore (2009), "Information Search and Consideration Set Formation in a Web-Based Store Environment," Journal of Business Research, 62(6), 644-650. Ratnasingham, Pauline (1998), "Internet Based EDI Trust and Security Information," $\mathrm{Ma}^{-}$ nagement and Computer Security, 6(1), 33-39.

Reibstein, David. J. (2002), "What Attracts Customers to Online Stores, and What Keeps Them Coming Back?" Journal of the Academy of Marketing Science, 30(4), 465-471.

Reichheld, Frederick F. and Phil Schefter(2000), "E-loyalty: Your Secret Weapon on the Web” Harvard Business Review, 78, 105

Ribbink, Dina, Allard C. R Riel, Veronica Liljander, and Sandra Streukens (2004), "Comfort Your Online Customer: Quality, Trust and Loyalty on the Internet," $\mathrm{Ma}^{-}$ naging Service Quality, 14(6), 446-456. 
Rust, Roland Z. and Anthony J. Zahorik (1993), "Customer Satisfaction, Customer Retention and Market Share," Journal of Retailing, 69(2), 193-215.

Sahadev, Sunil and Keyoor Purani (2008), "Modelling the Consequences of E-service Quality," Marketing Intelligence \& Planning, 26 (6), 605-620.

Schaffer, Eric (2000), "A better way for web design," InformationWeek, 784(May), 194.

Seiders, Kathleen, Glenn B. Voss, Andrea L. Godfrey, and Dhruv Grewal (2007), "SERVCON: Development and Validation of A Multidimensional Service Convenience Scale," Journal of the Academy of Marketing Science, 25(1), 144-156.

Seiders, Kathleen, Leonard L. Berry, and Larry G. Gresham (2000), "Attention retailers: How convenient is your convenience strategy?" Sloan Management Review, 49(3), 79-90.

Singh, Jagdip and Deepak Sirdeshmukh (2000), "Agency and Trust Mechanisms in Relational Exchanges," Journal of the Academy of Marketing Science, 28(1), 150-167.

Singh, Nitish, Hongxin Zhao, and Xiaorui Hu (2005), "Cultural Adaptation on the Web: A Study of American Companies' Domestic and Chinese Websites," Journal of Global Information Management, 11(3), 63-80.

Sinkovics, Rudolf R., MoYamin, Matthias Hossinger(2007), "Cultrual Adaptation in Cross Boreder E-commerce: A Study of German Companies," Journal of Electronic
Commerce Research,8(40),221-235.

Smith, J. Brock and Donald W. Barclay (1997), "The Effects of Organizational Differences and Trust on the Effectiveness of Selling Partner Relationships," Journal of Marketing, 61(1), 3-21.

Spekman, Robert E. (1988), "Perceptions of Strategic Vulnerability among Industrial Buyers and Its Effect on Information Search and Supplier Evaluation," Journal of Business Research, 17(4), 313-327.

Srinivasan, Srini S., Rolph Anderson, and Kishore Ponnavolu (2002), "Customer Loyalty in Ecommerce: an Exploration of Its Antecedents and Consequences," Journal of Retailing, 78(1), 41-50.

Straubhaar, Joseph and Robert LaRose (1996), "Communications Media in the Information Society," Belmont, CA: Wadsworth Press. Szymanski, David M. and Richard T. Hise (2000), "E-satisfaction: An Initial Examination," Journal of Retailing, 76(3), 309322.

Tang, See Kit (2014), "Why China-South Korea trade pact is a win-win," (accessed November 11, 2014), [available at http://www.cnbc. com/2014/11/11/why-china-south-koreatrade-pact-is-a-win-win.html.

Tenenhaus, Michel, Vincenzo E. Vinzi, Yves M. Chatelin, and Carlo Lauro (2005), "PLS Path Modeling," Computational Statistics \& Data Analysis, 48(1), 159-205.

Thorbjornsen, Helge, Magne Supphellen, Herbjorn 
Nysveen, and Per E. Pedersen (2002), "Building Brand Relationships Online: A Comparison of two Interactive Applications," Journal of Interactive Marketing, 16(3), 17-34.

Tracy, Bernadette (1998), "E-tailing: What Web Customers Really Want," Advertising Age's Business Marketing, 83(11), 39-42.

Urban, Glen L., Fareena Sultan and William Qualls (1999), "Design and Evaluation of a Trust Based Advisor on the Internet," research paper presented at the MIT Sloan School of Management (July 1999). Walter, J. O’Brien (2001), "Consumer Privacy Attitudes and Behaviors Survey Conducted by Harris Interactive," research paper pre- sented at Harris Interactive for the Privacy Leadership Initiative.

Watson, Richard T., Sigmund Akselsen, and Leyland F. Pitt (1998), "Attractors: Building Mountains in the Flat landscape of the World Wide Web," California Management Review, 40(2), 36-43.

Yale, L. and A. Venkatesh (1986), "Toward the Construct of Convenience in Consumer Research," Advances in Consumer Research, 13(1), 403-408.

Yoon, Sung Joon and Joo Ho Kim (2000), “An Empirical Validation of a Loyalty Model Based on Expectation Disconfirmation," Journal of Consumer Marketing, 17(2), 120-126. 


\section{$\langle$ Appendix I〉}

Constructs and measurement items

\begin{tabular}{|c|c|c|c|}
\hline $\begin{array}{l}\text { Second-order } \\
\text { Variables }\end{array}$ & $\begin{array}{l}\text { First-order } \\
\text { Variables }\end{array}$ & & Questionnaire \\
\hline \multirow{12}{*}{ Trustworthiness } & \multirow{3}{*}{$\begin{array}{l}\text { Security } \\
\text { assurance }\end{array}$} & Se1 & (This site) presented security assurance words in detail \\
\hline & & $\mathrm{Se} 2$ & (This site) presented privacy agreement words in detail \\
\hline & & Se3 & (This site) assured safe transactions \\
\hline & \multirow{2}{*}{ Delivery service } & $\overline{\text { Del }}$ & (This site) delivered products at promised time \\
\hline & & De2 & (This site) was easy to return the product delivery \\
\hline & \multirow{3}{*}{ Product quality } & Qual & (This site) deals products with high quality \\
\hline & & Qua2 & (This site) deals various products \\
\hline & & Qua3 & (This site) supports high product availability \\
\hline & \multirow{4}{*}{$\begin{array}{l}\text { Size \& } \\
\text { Reputation }\end{array}$} & Sizel & (This site) is well known \\
\hline & & Size2 & (This site) has a good reputation \\
\hline & & Size3 & (This site) has a big size \\
\hline & & Size4 & (This site) has lots of own members \\
\hline \multirow{10}{*}{ Interactivity } & \multirow{3}{*}{ Active Control } & Act1 & (At this site) I had a lot of control over my visiting experience \\
\hline & & Act2 & (At this site) I could choose freely what I wanted to see \\
\hline & & Act3 & (At this site) my actions decided the kind of experiences I got \\
\hline & \multirow{4}{*}{$\begin{array}{l}\text { Two-way } \\
\text { Communication }\end{array}$} & Two1 & (This site) was effective in gathering visitors' feedback \\
\hline & & Two2 & (This site) facilitated two-way communication with visitors \\
\hline & & Two3 & (This site) made me feel it wants to listen to its visitors \\
\hline & & Two4 & (This site) gave visitors the opportunity to talk back \\
\hline & \multirow{3}{*}{ Synchronicity } & Syn1 & (This site) processed my input very quickly \\
\hline & & Syn2 & It was very fast to get information from this site \\
\hline & & Syn3 & I was able to obtain the information I want without delay \\
\hline \multirow{9}{*}{ Convenience } & \multirow{3}{*}{$\begin{array}{l}\text { Access } \\
\text { convenience }\end{array}$} & Acc1 & It was easy to find this website. \\
\hline & & Acc2 & I was able to access this website easily \\
\hline & & Acc3 & I can visit this website anytime, anywhere \\
\hline & \multirow{3}{*}{$\begin{array}{l}\text { Transaction } \\
\text { convenience }\end{array}$} & Tran1 & I was able to complete my purchase quickly at this site \\
\hline & & Tran2 & (This site) made it easy for me to conclude my transaction \\
\hline & & Tran3 & It took little time to pay for my products \\
\hline & \multirow{3}{*}{$\begin{array}{l}\text { Benefit } \\
\text { convenience }\end{array}$} & Ben1 & (This site) recommended suitable products for me \\
\hline & & Ben2 & It was easy to evaluate products at this website \\
\hline & & Ben3 & I could find the products I am looking for at this site \\
\hline \multirow{3}{*}{ Satisfactory } & & Sat1 & I was satisfied with my decision to purchase from this site \\
\hline & & Sat2 & It was a wise choice to purchase from this website \\
\hline & & Sat3 & I think I did the right thing by buying from this site \\
\hline \multirow{5}{*}{ Loyalty } & & Loy1 & I try to use the site whenever I need to make a cross-border purchase \\
\hline & & Loy2 & This site is my first choice when I need to make a purchase \\
\hline & & Loy3 & I like using this website \\
\hline & & Loy4 & To me this is the best cross-border site to do business with \\
\hline & & Loy5 & I believe that this is my favorite retail website \\
\hline
\end{tabular}

